\title{
Combination of Matrine and Sorafenib Decreases the Aggressive Phenotypes of Hepatocellular Carcinoma Cells
}

\author{
Yan Lin Lianjie Lin Yu Jin Ying Zhang Dongxu Wang Yue Tan \\ Changqing Zheng \\ Department of Gastroenterology, Shengjing Hospital of China Medical University, Shenyang, China
}

\section{Key Words}

Apoptosis · Combination therapy · Growth suppression · Matrine $\cdot$ microRNA

\begin{abstract}
Background: The aim of this study was to determine the effects of matrine (a natural alkaloid) on sorafenib-induced cytotoxicty against hepatocellular carcinoma (HCC) cells, and to explore the molecular mechanisms involved. Methods: HepG2 and Hep3B cells were treated with matrine alone or in combination with sorafenib, and cell viability and apoptosis were assessed. The involvement of micro (mi)RNA-21 in the action of matrine was examined. Results: Matrine significantly augmented the antiproliferative activity of sorafenib in a dose-dependent manner. Matrine significantly increased apoptosis, coupled with enhanced cleavage of caspase-3 and poly (ADP-ribose) polymerase. miRNA21-overexpressing HCC cells showed a marked decrease in matrine-induced growth suppression and the expression of phosphatase and tensin homolog (PTEN). The suppressive effect of combining matrine and sorafenib was significantly reduced by miRNA-21 overexpression or PTEN inhibition. Conclusion: Matrine in combination with sorafenib leads to increased cytotoxic effects against HCC cells, at least partially, via the suppression of miRNA-21 and the subsequent induction of PTEN.

(c) 2015 S. Karger AG, Basel
\end{abstract}

(C) 2015 S. Karger AG, Basel

0009-3157/15/0602-0112\$39.50/0

\section{Introduction}

Hepatocellular carcinoma (HCC) is the third leading cause of cancer-related deaths worldwide [1]. The poor prognosis of HCC largely results from the asymptomatic nature of the early stage of the disease [2]. For advanced HCC, no effective therapies are currently available. Sorafenib (previously known as BAY 43-9006) is the first oral multi-kinase inhibitor and shows cytotoxic effects against a variety of cancers [3]. Sorafenib has been approved by the US Food and Drug Administration for the treatment of advanced HCC. Two randomized, placebocontrolled, phase III trials have demonstrated that sorafenib offers survival benefits to patients with advanced HCC; however, the improvement in overall survival is limited, with only 2-3 months of prolongation [4, 5]. At present, many attempts have been made to develop a sorafenib-based combination with other anticancer reagents to improve therapeutic efficacy [6].

Matrine is one of the major alkaloid components of Sophora flavescens Ait, a traditional Chinese medicine, and possesses a variety of pharmacological effects, including anticancer effects [7]. It has been documented that matrine induces growth inhibition and apoptosis in V600EBRAF-harboring melanoma cells via the activation of phosphatase and tensin homolog (PTEN), a wellknown tumor suppressor [8]. Zhang et al. [9] reported that matrine promotes apoptosis in human acute myeloid

\section{KARGER}

E-Mail karger@karger.com

www.karger.com/che
Changqing Zheng

Shengjing Hospital of China Medical University

39 Huaxiang Road

Tiexi District, Shenyang 110001 (China)

E-Mail changq_zheng@163.com 
leukemia cells via the activation of caspase-3. Caspase- 3 activation and subsequent cleavage of poly (ADPribose) polymerase (PARP) play a critical role in mediating apoptosis $[10,11]$. Matrine also exerts anticancer activity in HCC cells. It has been reported that matrine inhibits cell proliferation in human HCC HepG2 cells [12]. Zhang et al. [13] confirmed that matrine causes growth suppression and promotes apoptotic and autophagic death in HCC cells. When used with conventional chemotherapeutic agents, matrine was found to provide synergistic inhibitory effects on tumor growth in an animal model of gastric cancer [14]. However, its effect on the efficacy of sorafenib in HCC is still not known.

In breast cancer, matrine has been found to inhibit cell growth via the modulation of the micro (mi)RNA-21/ PTEN/Akt pathway [15]. miRNAs are a large class of small noncoding RNAs involved in the posttranscriptional regulation of target genes $[16,17]$. Compelling evidence indicates that miRNA-21 plays an oncogenic role in HCC by promoting cell proliferation, migration and invasion, which are causally linked to targeting PTEN [18].

In this study, we explored the combined effects of sorafenib and matrine on HCC cell proliferation and apoptosis and checked whether the anticancer property of matrine in HCC was mediated by modulation of the miRNA-21/PTEN axis.

\section{Materials and Methods}

\section{Reagents and Antibodies}

Dulbecco's modified Eagle medium, fetal bovine serum, penicillin, streptomycin and Lipofectamine 2000 transfection reagent were purchased from Invitrogen (Carlsbad, Calif., USA), miRNA-21 mimic, negative mimic and mirVana miRNA isolation kit from Ambion (Foster City, Calif., USA), PTEN small interfering RNA (siRNA) and control siRNA from Cell Signaling Technology (Beverly, Mass., USA), Taqman miRNA assays from Applied Biosystems (Foster City, Calif., USA), 3-(4,5-dimethylthiazol2-yl)-2,5-diphenyltetrazoliumbromide (MTT), phenylmethylsulfonyl fluoride, aprotonin, leupeptin and sodium orthovanadate from Sigma-Aldrich (St. Louis, Mo., USA), an annexin V apoptosis kit from Becton Dickinson Biosciences (San Diego, Calif., USA) and enhanced chemiluminescence reagents from Amersham Biosciences (Piscataway, N.J., USA). Rabbit anti-cleaved caspase-3, anti-cleaved PARP, anti-PTEN and anti- $\beta$-actin antibodies were purchased from Cell Signaling Technology. Horseradish peroxidase-conjugated goat anti-rabbit secondary antibody was purchased from Santa Cruz Biotechnology (Santa Cruz, Calif., USA).

\section{Cell Culture}

Human HCC cells (HepG2 and Hep3B) were purchased from the American Type Culture Collection (Manassas, Va., USA). They were maintained in Dulbecco's modified Eagle medium supplement with $10 \%$ fetal bovine serum, $100 \mathrm{U} / \mathrm{ml}$ penicillin and $100 \mu \mathrm{g} / \mathrm{ml}$ streptomycin at $37^{\circ} \mathrm{C}$ in a $5 \% \mathrm{CO}_{2}$ humidified incubator.

\section{Cell Treatment and Transfection}

HepG2 and Hep3B cells at a density of $4 \times 10^{5}$ cells/well in 6 -well plates or $3 \times 10^{3}$ cells/well in 96-well plates were exposed to sorafenib at $2.5 \mu \mathrm{M}$ [19] for $48 \mathrm{~h}$ in the presence or absence of different concentrations $(0.4-1.6 \mathrm{~g} / \mathrm{l})$ of matrine. After treatment, cells were tested for proliferation and apoptosis. For transient overexpression of miRNA-21, cells were transfected with $50 \mathrm{nM}$ miRNA-21 mimic or negative mimic using Lipofectamine 2000 transfection reagent. For knockdown of PTEN expression, cells were transiently transfected with PTEN or control siRNA at a concentration of $100 \mathrm{nM}$, using Lipofectamine 2000 Transfection reagent. After incubation for $24 \mathrm{~h}$, the transfected cells were treated with matrine $(0.4 \mathrm{~g} / \mathrm{l})$ alone or along with sorafenib. The cells were collected $48 \mathrm{~h}$ later and tested for proliferation.

\section{miRNA-21 Expression Analysis}

Total RNA was isolated from cells using the mirVana miRNA isolation kit, according to the manufacturer's instructions. The expression level of mature miRNA-21 was determined using Taqman miRNA assays. Briefly, cDNA was synthesized with an miRNA-specific stem-loop primer, and quantitative PCR was performed using specific TaqMan microRNA assay primers. The relative miRNA-21 amount normalized to the U6 small nuclear RNA level was calculated using the comparative cycle threshold $(\Delta \Delta \mathrm{Ct})$ method [20]. Each assay was carried out in triplicate.

\section{Cell Proliferation Assay}

Cell proliferation was determined using the MTT method. Briefly, after drug treatment for $48 \mathrm{~h}$, the MTT solution $(5 \mathrm{mg} / \mathrm{ml})$ was added to the cell cultures and incubated at $37^{\circ} \mathrm{C}$ for $4 \mathrm{~h}$. After the removal of MTT, dimethyl sulfoxide solution was added to dissolve formazan crystals. Absorbance was measured at a wavelength of $570 \mathrm{~nm}$. Triplicate wells were tested for each treatment.

Apoptosis Analysis by Annexin-V/Propidium Iodide Staining

After drug treatment, cells were harvested by trypsinization and resuspended in phosphate-buffered saline. Cell apoptosis was determined using the annexin $\mathrm{V}$ apoptosis kit. The cells were stained with fluorescein isothiocyanate-conjugated annexin $\mathrm{V}$ and propidium iodide solution $(20 \mu \mathrm{g} / \mathrm{ml})$ for $15 \mathrm{~min}$ in the dark. Apoptotic cells (annexin V-positive) were analyzed by flow cytometry (Becton Dickinson Biosciences). Each assay was performed in triplicate.

\section{Western Blot Analysis}

Cells were rinsed with ice-cold phosphate-buffered saline and lysed in lysis buffer (10 mM Tris/HCl pH 6.8, 10\% glycerol, $2 \%$ sodium dodecyl sulfate, $1 \%$ Triton X-100, 1\% Nonidet P-40) containing $1 \mathrm{~mm}$ phenylmethylsulfonyl fluoride, $10 \mu \mathrm{g} / \mathrm{ml}$ aprotinin, 10 $\mu \mathrm{g} / \mathrm{ml}$ leupeptin and $1 \mathrm{~mm}$ sodium orthovanadate. Cell lysates were separated by sodium dodecyl sulfate-polyacrylamide gel electrophoresis and transferred to polyvinylidene fluoride membranes (Millipore, Bedford, Mass., USA). Membranes were incubated in blocking solution, probed with various antibodies, and then visualized by means of horseradish peroxidase-conjugated secondary 


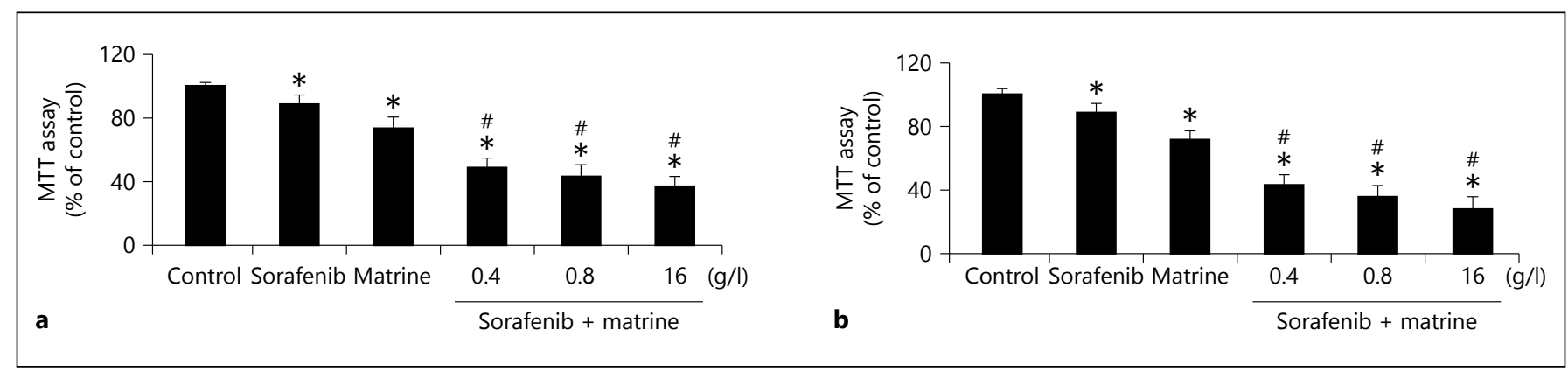

Fig. 1. Effects of sorafenib and matrine alone or in combination on HCC cell proliferation. HepG2 (a) and Hep3B cells $(\mathbf{b})$ were exposed to sorafenib $(2.5 \mu \mathrm{M})$ or matrine $(0.4 \mathrm{~g} / \mathrm{l})$ alone or the combination of sorafenib with matrine at $0.4,0.8$ and $1.6 \mathrm{~g} / \mathrm{l}$. After 48 -hour incu- bation, cell proliferation was determined using the MTT assay. The proliferation in untreated cells (control) was arbitrarily assigned $100 \%{ }^{*} \mathrm{p}<0.05$ vs. control; ${ }^{\#} \mathrm{p}<0.05$ vs. sorafenib or matrine alone.

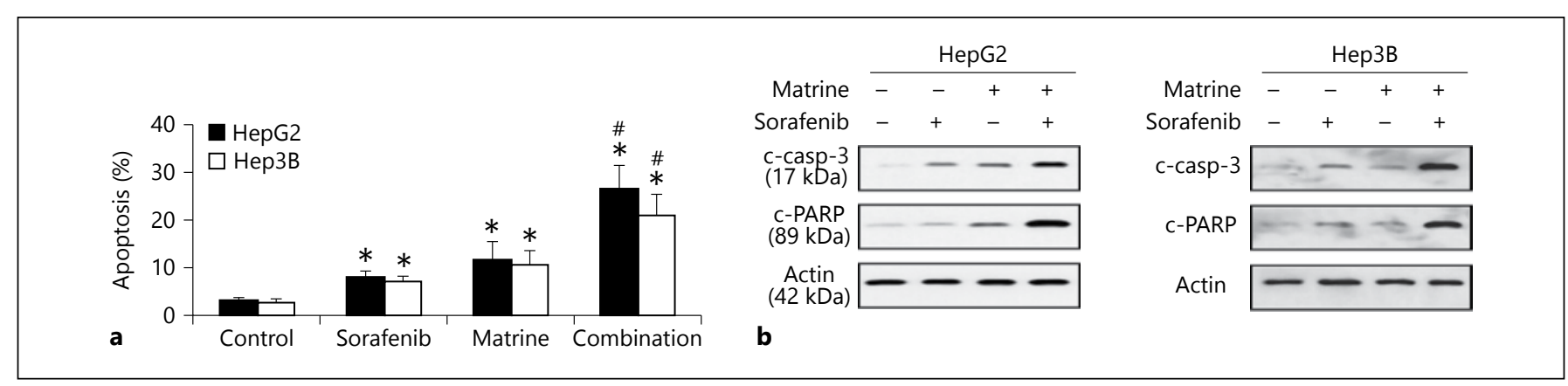

Fig. 2. Effects of sorafenib and matrine alone or in combination on apoptosis of HCC cells. HepG2 and Hep3B cells were exposed to sorafenib $(2.5 \mu \mathrm{M})$ and matrine $(0.4 \mathrm{~g} / \mathrm{l})$ alone or in combination. After 48-hour incubation, cell apoptosis was assessed. a The cells were stained with annexin $\mathrm{V}$ and propidium iodide and the percentage of apoptotic cells was determined using flow cytometry.

antibodies and enhanced chemiluminescence reagents. Densitometry was performed using Quantity One software (Bio-Rad, Hercules, Calif., USA).

\section{Statistical Analysis}

Data are presented as means \pm standard deviation. The difference among the means of multiple groups was analyzed by oneway analysis of variance (ANOVA) followed by the Tukey test. A $p$ value of $<0.05$ was considered statistically significant.

\section{Results}

\section{Matrine Augments the Antiproliferative Effect of \\ Sorafenib in HCC Cells}

Compared to untreated control, sorafenib $(2.5 \mu \mathrm{M})$ or matrine $(0.4 \mathrm{~g} / \mathrm{l})$ alone caused a $10-30 \%$ reduction in the proliferation of HepG2 (fig. 1a) and Hep3B (fig. 1b) cells
* $\mathrm{p}<0.05$ vs. control; ${ }^{\#} \mathrm{p}<0.05$ vs. sorafenib or matrine alone. b Cells were tested for apoptotic markers by Western blot analysis. Representative blots of 3 independent experiments with similar results are shown. $\beta$-Actin was used as the loading control. c-casp-3 = Cleaved caspase-3; c-PARP = cleaved PARP.

after 48-hour incubation. The combination with matrine significantly $(\mathrm{p}<0.05)$ augmented the antiproliferative activity of sorafenib in HCC cells, compared to sorafenib alone. In the presence of matrine $(0.4 \mathrm{~g} / \mathrm{l})$, sorafenib treatment inhibited the proliferation of HepG2 and Hep3B cells by 52 and $57 \%$, respectively ( $p<0.05$ vs. untreated control). If not stated otherwise, the concentration of matrine used in the following experiments was $0.4 \mathrm{~g} / \mathrm{l}$.

\section{Combining Sorafenib with Matrine Enhances}

Apoptotic Death of HCC Cells

Exposure to sorafenib or matrine alone led to modest apoptosis in HepG2 cells (7.8 \pm 1.2 and $11.5 \pm 3.7 \%$, respectively) relative to control ( $2.9 \pm 0.6 \%$; fig. $2 \mathrm{a})$. Notably, the combination of sorafenib with matrine promoted significant apoptosis in HepG2 cells, with an apoptotic rate of $26.5 \pm 4.8 \%$. Similar proapoptotic effects of combined 


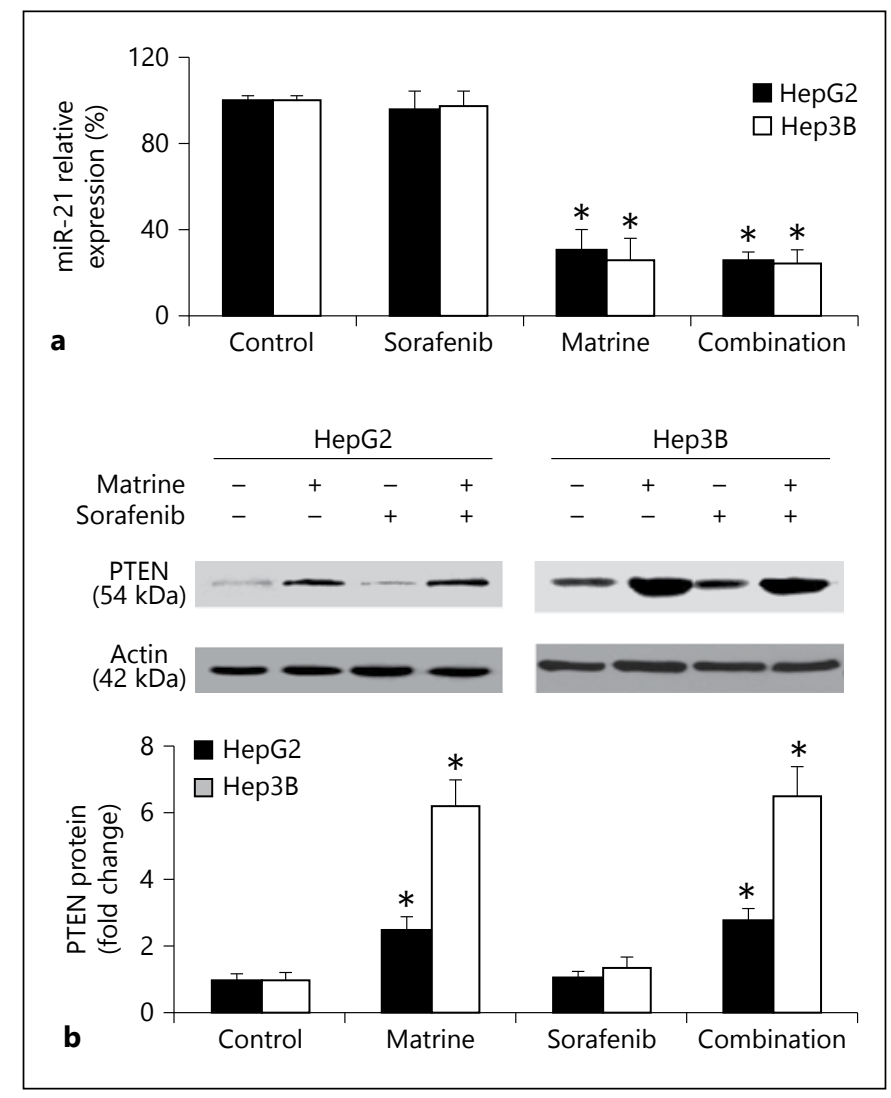

Fig. 3. Effects of matrine and sorafenib alone or in combination on miRNA-21 and PTEN expression. Cells were treated with sorafenib $(2.5 \mu \mathrm{M})$ and matrine $(0.4 \mathrm{~g} / \mathrm{l})$ alone or in combination for $48 \mathrm{~h}$ and tested for gene expression. a Real-time PCR analysis was done to measure miRNA-21 expression changes. The miRNA-21 expression level in untreated cells (control) was arbitrarily assigned $100 \%$. Data are representative of 3 independent experiments. b Western blot analysis of PTEN protein levels. Top panels show representative blots of 3 independent experiments. Bottom panels demonstrate densitometric analysis of PTEN protein expression. Data are expressed as fold change of control. ${ }^{*} \mathrm{p}<0.05$ vs. control.

sorafenib and matrine treatment were observed in Hep3B cells (fig. 2a). Western blot analysis demonstrated that treatment with combined sorafenib and matrine resulted in a marked enhancement in the cleavage of caspase- 3 and PARP, compared to treatment with each alone (fig. $2 b$ ).

\section{Exposure to Matrine but Not Sorafenib Inhibits}

miRNA-21 and Increases PTEN in HCC Cells

Real-time PCR analysis revealed that exposure to matrine significantly $(\mathrm{p}<0.05)$ decreased the expression of miRNA-21 in HepG2 and Hep3B cells, compared to control cells (fig. 3a). The miRNA-21 expression was similarly reduced in HCC cells with combined sorafenib and matrine. However, sorafenib treatment had no significant effect on miRNA-21 expression in HCC cells. Western blot analysis revealed that matrine significantly induced the PTEN protein expression in HCC cells, but such induction was not enhanced by combined matrine and sorafenib (fig. 3b).

\section{miRNA-21 Overexpression Antagonizes the}

Anticancer Activity of Matrine Alone or in

Combination with Sorafenib by Targeting PTEN

MTT assay revealed that pretransfection with miRNA-21 mimic almost completely abrogated matrine $(0.4 \mathrm{~g} / \mathrm{l})$-induced growth suppression in HepG2 and Hep3B cells (fig. 4a). miRNA-21 overexpression significantly $(\mathrm{p}<0.05)$ blocked the induction of PTEN expression by matrine alone (fig. $4 \mathrm{~b}$ ). Similar to overexpression of miRNA-21, the repression of PTEN expression with siRNA significantly $(\mathrm{p}<0.05)$ reduced the growth suppression by matrine in HCC cells (fig. 4c). Western blot analysis confirmed the effective reduction of PTEN protein in HCC cells by the delivery of PTEN siRNA but not control siRNA (fig. 4d). The inhibition of HCC cell proliferation by combining matrine and sorafenib was significantly counteracted by pretransfection with miRNA-21 mimic or PTEN siRNA (fig. 4a, c).

\section{Discussion}

Sorafenib administration has become a new standard therapy for patients with advanced HCC [5]. To improve its therapeutic efficacy, many sorafenib-based combined modalities have been tested [21-23]. However, their overall outcomes are unsatisfactory. There is an urgent need for the development of novel therapeutic approaches to advanced HCC. The combination of sorafenib with bioactive natural compounds may lead to increased therapeutic efficacy. For instance, Wan et al. [24] reported that combined treatment with sorafenib and tetrandrine induces synergistic apoptosis in cancer cells via the activation of reactive oxygen species/Akt signaling. Cohen et al. [25] demonstrated that a combination of sorafenib with withaferin $\mathrm{A}$, a natural withanolide, significantly enhances apoptotic death in both papillary and anaplastic thyroid cancer cells. Our data showed that the combination of sorafenib and matrine caused a significant increase in growth suppression and apoptosis induction, relative to each agent alone. At the molecular level, combined treatment with sorafenib and matrine resulted in a marked elevation in the cleavage of 

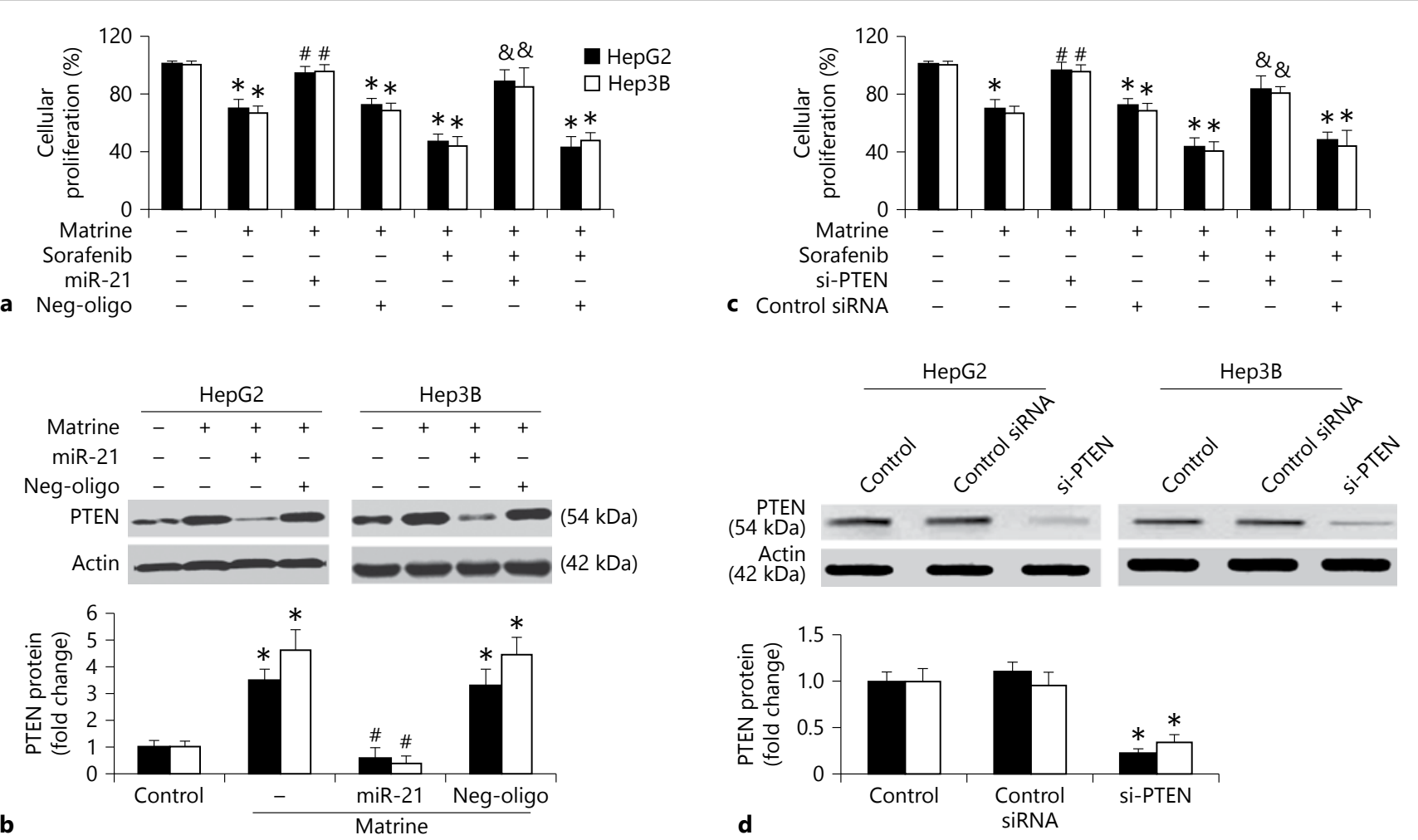

Fig. 4. The miRNA-21/PTEN axis mediates the effects of matrine on the proliferation of HCC cells. Cells were pretransfected with miRNA-21 mimic or negative control oligonucleotides (Neg-oligo), followed by exposure to matrine alone or in combination with sorafenib for $48 \mathrm{~h}$. a Cell proliferation was determined using the MTT assay. The proliferation in untreated cells (control) was arbitrarily assigned $100 \%{ }^{*} \mathrm{p}<0.05$ vs. control; ${ }^{\#} \mathrm{p}<0.05$ vs. matrine alone; ${ }^{\&} \mathrm{p}<0.05$ vs. combined matrine and sorafenib. b Western blot analysis of PTEN protein levels. Top panels show representative blots of 3 independent experiments. Bottom panels demonstrate densitometric analysis of PTEN protein expression. Data are

expressed as fold change of control. ${ }^{*} \mathrm{p}<0.05$ vs. control; ${ }^{\#} \mathrm{p}<0.05$ vs. matrine alone. $c$ Cells were pretransfected with PTEN siRNA (si-PTEN) or control siRNA and treated with matrine alone or in combination with sorafenib for $48 \mathrm{~h}$. Cell proliferation was examined using the MTT assay. ${ }^{*} \mathrm{p}<0.05$ vs. control; ${ }^{\#} \mathrm{p}<0.05$ vs. matrine alone; ${ }^{\&} \mathrm{p}<0.05$ vs. combined matrine and sorafenib. d Western blot analysis of PTEN protein levels in HCC cells transfected with si-PTEN or control siRNA. Top panels show representative blots of 3 independent experiments. Bottom panels show densitometric results. ${ }^{*} \mathrm{p}<0.05$ vs. control (untreated cells).

caspase- 3 and PARP, two indicators of caspase-mediated apoptosis. To the best of our knowledge, this is the first report about the synergistic anticancer activity of sorafenib and matrine.

Matrine shows cytotoxic effects against various cancers, including melanoma [8], acute myeloid leukemia [9] and HCC [12]. Zhang et al. [13] reported that matrine is capable of inducing apoptosis and autophagy in HCC cells. Our data confirmed the proapoptotic activity of matrine in HCC cells, which was associated with the promotion of caspase-3 and PARP cleavage. Induction of caspase-3-mediated apoptosis by matrine has also been described in several other types of cancer cells such as gastric cancer cells [26]. Reduced expression of oncogenes rep-

resents an important mechanism for suppressing tumor growth. miRNA-21 has been found to act as an oncogene in HCC by accelerating tumor cell proliferation, migration and invasion [18]. Notably, our data revealed that matrine treatment resulted in a significant reduction in miRNA-21 expression in HCC cells. Ectopic expression of miRNA-21 antagonized the reduction in the proliferation of matrine-treated HCC cells. Likewise, matrine-induced growth suppression was impaired by pretransfection of PTEN siRNA. PTEN has been identified as a direct target of miRNA-21 [18]. Consistently, our data demonstrated that miRNA-21 overexpression repressed the PTEN expression in matrine-treated HCC cells. PTEN is a potent tumor suppressor and its upregulation by phar- 
macological or genetic approaches leads to apoptotic death in tumor cells $[27,28]$. Taken together, our data suggest that matrine upregulates the expression of PTEN via the inhibition of miRNA-21 expression, which in turn contributes to apoptotic death in HCC cells. The modulation of the miRNA-21/PTEN axis by matrine has also been reported in breast cancer cells [15].

Several miRNAs have been found to be involved in the sensitivity of HCC cells to sorafenib [29, 30]. For instance, Bai et al. [29] demonstrated that miRNA-122-expressing HCC cells are more susceptible to sorafenib than those lacking miRNA-122 expression. Similarly, the expression of let-7 miRNAs potentiates sorafenib-induced apoptosis in HCC cells via targeting the antiapoptotic protein, Bcl$\mathrm{xL}$ [30]. The delivery of miRNA-193b [31] and miRNA193a [32] also sensitizes HCC cells to sorafenib cytotoxicity. We showed that in contrast to matrine, sorafenib failed to alter the expression of miRNA-21 in HCC cells. Most interestingly, the delivery of either miRNA-21 mimic or PTEN siRNA significantly blocked the growth inhibition induced by combined treatment with matrine and sorafenib. These results indicate that matrine-mediated sensitization to sorafenib is at least partially attributable to alteration of the miRNA-21/PTEN signaling. miRNA-21 has been shown to confer resistance to interferon- $\alpha$ and 5-fluorouracil in HCC cells [33]. Our findings further highlight the role of miRNA-21 in regulating the susceptibility of HCC cells to systemic therapeutic agents.

In conclusion, our data show that the anticancer activity of matrine alone or in combination with sorafenib in HCC is mediated, at least partially, by suppression of miRNA-21 and subsequent upregulation of PTEN. Matrine represents a promising natural compound for use in the enhancement of the therapeutic efficacy of sorafenib in HCC.

\section{Acknowledgements}

This study was supported by the Science and Technology Project of Shenyang, China (No. F13-318-1-42).

\section{References}

1 Verslype C, Rosmorduc O, Rougier P; ESMO Guidelines Working Group: Hepatocellular carcinoma: ESMO-ESDO clinical practice guidelines for diagnosis, treatment and followup. Ann Oncol 2012;23(suppl 7):vii41-vii48.

2 Wang X, Zhang A, Sun H: Power of metabolomics in diagnosis and biomarker discovery of hepatocellular carcinoma. Hepatology 2013;57:2072-2077.

3 Park SJ, Lee JL, Park I, Park K, Ahn Y, Ahn JH, Lee DH, Ahn S, Song C, Hong JH, Kim CS, Ahn H: Comparative efficacy of sunitinib versus sorafenib as first-line treatment for patients with metastatic renal cell carcinoma. Chemotherapy 2012;58:468-474.

4 Cheng AL, Kang YK, Chen Z, Tsao CJ, Qin S, Kim JS, Luo R, Feng J, Ye S, Yang TS, Xu J, Sun Y, Liang H, Liu J, Wang J, Tak WY, Pan H, Burock K, Zou J, Voliotis D, Guan Z: Efficacy and safety of sorafenib in patients in the Asia-Pacific region with advanced hepatocellular carcinoma: a phase III randomised, double-blind, placebo-controlled trial. Lancet Oncol 2009; 10:25-34.

5 Llovet JM, Ricci S, Mazzaferro V, Hilgard P, Gane E, Blanc JF, de Oliveira AC, Santoro A, Raoul JL, Forner A, Schwartz M, Porta C, Zeuzem S, Bolondi L, Greten TF, Galle PR, Seitz JF, Borbath I, Häussinger D, Giannaris T, Shan M, Moscovici M, Voliotis D, Bruix J; SHARP Investigators Study Group: Sorafenib in advanced hepatocellular carcinoma. $\mathrm{N}$ Engl J Med 2008;359:378-390.
6 Abdel-Rahman O, Fouad M: Sorafenib-based combination as a first line treatment for advanced hepatocellular carcinoma: a systematic review of the literature. Crit Rev Oncol Hematol 2014;91:1-8.

7 Liu Y, Xu Y, Ji W, Li X, Sun B, Gao Q, Su C: Anti-tumor activities of matrine and oxymatrine: literature review. Tumour Biol 2014;35: 5111-5119.

$>8$ Jin $\mathrm{H}$, Sun Y, Wang S, Cheng X: Matrine activates PTEN to induce growth inhibition and apoptosis in V600EBRAF harboring melanoma cells. Int J Mol Sci 2013;14:1604016057.

-9 Zhang S, Zhang Y, Zhuang Y, Wang J, Ye J, Zhang S, Wu J, Yu K, Han Y: Matrine induces apoptosis in human acute myeloid leukemia cells via the mitochondrial pathway and Akt inactivation. PLoS One 2012;7:e46853.

10 Vermeulen K, Van Bockstaele DR, Berneman $\mathrm{ZN}$ : Apoptosis: mechanisms and relevance in cancer. Ann Hematol 2005;84:627-639.

$\checkmark 11$ Fauser JK, Matthews GM, Cummins AG, Howarth GS: Induction of apoptosis by the medium-chain length fatty acid lauric acid in colon cancer cells due to induction of oxidative stress. Chemotherapy 2013;59:214-224.

12 Qin XG, Hua Z, Shuang W, Wang YH, Cui YD: Effects of matrine on HepG2 cell proliferation and expression of tumor relevant proteins in vitro. Pharm Biol 2010;48:275-281.

$\checkmark 13$ Zhang JQ, Li YM, Liu T, He WT, Chen YT, Chen XH, Li X, Zhou WC, Yi JF, Ren ZJ: An- titumor effect of matrine in human hepatoma G2 cells by inducing apoptosis and autophagy. World J Gastroenterol 2010;16:42814290.

14 Hu MJ, Zeng H, Wu YL, Zhang YP, Zhang S, Qiao MM, Fu H: Synergistic effects of matrine and 5-fluorouracil on tumor growth of the implanted gastric cancer in nude mice. Chin J Dig Dis 2005;6:68-71.

15 Li LQ, Li XL, Wang L, Du WJ, Guo R, Liang HH, Liu X, Liang DS, Lu YJ, Shan HL, Jiang HC: Matrine inhibits breast cancer growth via miR-21/PTEN/Akt pathway in MCF-7 cells. Cell Physiol Biochem 2012;30:631-641.

16 van Rooij E: The art of microRNA research. Circ Res 2011;108:219-234.

$\checkmark 17$ Li Z, Rana TM: Therapeutic targeting of microRNAs: current status and future challenges. Nat Rev Drug Discov 2014;13:622638 .

18 Meng F, Henson R, Wehbe-Janek H, Ghoshal K, Jacob ST, Patel T: MicroRNA-21 regulates expression of the PTEN tumor suppressor gene in human hepatocellular cancer. Gastroenterology 2007;133:647-658.

19 Wei G1, Wang M, Hyslop T, Wang Z, Carr BI Vitamin $\mathrm{K}$ enhancement of sorafenib-mediated $\mathrm{HCC}$ cell growth inhibition in vitro and in vivo. Int J Cancer 2010;127:2949-2958.

20 Livak KJ, Schmittgen TD: Analysis of relative gene expression data using real-time quantitative PCR and the $2-\Delta \Delta \mathrm{Ct}$ method. Methods 2001;25:402-408. 
21 Naqi N, Ahmad S, Murad S, Khattak J: Efficacy and safety of sorafenib-gemcitabine combination therapy in advanced hepatocellular carcinoma: an open-label phase II feasibility study. Hematol Oncol Stem Cell Ther 2014;7:27-31.

22 Hagihara A, Ikeda M, Ueno H, Morizane C, Kondo S, Nakachi K, Mitsunaga S, Shimizu S, Kojima Y, Suzuki E, Katayama K, Imanaka K, Tamai C, Inaba Y, Sato Y, Kato M, Okusaka T: Phase I study of combination chemotherapy using sorafenib and transcatheter arterial infusion with cisplatin for advanced hepatocellular carcinoma. Cancer Sci 2014;105:354-358.

23 Finn RS, Poon RT, Yau T, Klümpen HJ, Chen LT, Kang YK, Kim TY, Gomez-Martin C, Rodriguez-Lope C, Kunz T, Paquet T, Brandt U, Sellami D, Bruix J: Phase I study investigating everolimus combined with sorafenib in patients with advanced hepatocellular carcinoma. J Hepatol 2013;59:1271-1277.

-24 Wan J, Liu T, Mei L, Li J, Gong K, Yu C, Li W: Synergistic antitumour activity of sorafenib in combination with tetrandrine is mediated by reactive oxygen species (ROS)/Akt signaling. Br J Cancer 2013;109:342-350.
25 Cohen SM, Mukerji R, Timmermann BN, Samadi AK, Cohen MS: A novel combination of withaferin A and sorafenib shows synergistic efficacy against both papillary and anaplastic thyroid cancers. Am J Surg 2012;204:895900.

26 Dai ZJ, Gao J, Ji ZZ, Wang XJ, Ren HT, Liu XX, Wu WY, Kang HF, Guan HT: Matrine induces apoptosis in gastric carcinoma cells via alteration of Fas/FasL and activation of caspase-3. J Ethnopharmacol 2009;123:9196.

27 Xie F1, Su M, Qiu W, Zhang M, Guo Z, Su B, Liu J, Li X, Zhou L: Kaempferol promotes apoptosis in human bladder cancer cells by inducing the tumor suppressor, PTEN. Int J Mol Sci 2013;14:21215-21226.

28 Li D, Zhang Y, Xie Y, Xiang J, Zhu Y, Yang J: Enhanced tumor suppression by adenoviral PTEN gene therapy combined with cisplatin chemotherapy in small-cell lung cancer. Cancer Gene Ther 2013;20:251-259.

29 Bai S, Nasser MW, Wang B, Hsu SH, Datta J, Kutay H, Yadav A, Nuovo G, Kumar P, Ghoshal K: MicroRNA-122 inhibits tumorigenic properties of hepatocellular carcinoma cells and sensitizes these cells to sorafenib. J Biol Chem 2009;284:32015-32027.
30 Shimizu S, Takehara T, Hikita H, Kodama T, Miyagi T, Hosui A, Tatsumi T, Ishida $\mathrm{H}$, Noda T, Nagano H, Doki Y, Mori M, Hayashi $\mathrm{N}$ : The let-7 family of microRNAs inhibits $\mathrm{Bcl}-\mathrm{xL}$ expression and potentiates sorafenibinduced apoptosis in human hepatocellular carcinoma. J Hepatol 2010;52:698-704.

31 Mao K, Zhang J, He C, Xu K, Liu J, Sun J, Wu G, Tan C, Zeng Y, Wang J, Xiao Z: Restoration of miR-193b sensitizes Hepatitis B virus-associated hepatocellular carcinoma to sorafenib. Cancer Lett 2014;352:245-252.

32 Salvi A, Conde I, Abeni E, Arici B, Grossi I, Specchia C, Portolani N, Barlati S, De Petro G: Effects of miR-193a and sorafenib on hepatocellular carcinoma cells. Mol Cancer 2013;12: 162.

33 Tomimaru Y, Eguchi H, Nagano H, Wada H, Tomokuni A, Kobayashi S, Marubashi S, Takeda Y, Tanemura M, Umeshita K, Doki Y, Mori M: MicroRNA-21 induces resistance to the anti-tumour effect of interferon- $\alpha / 5$ fluorouracil in hepatocellular carcinoma cells. Br J Cancer 2010;103:1617-1626. 